\title{
Analisis Pelaksanaan Program Adiwiyata Di Kota Makassar
}

\author{
Seprian Patandianan ${ }^{1)}$, Lahming ${ }^{1)}$, Moh. Ahsan S. Mandra ${ }^{1)}$ \\ ${ }^{1)}$ PPs Kependudukan dan Lingkungan Hidup, Universitas Negeri Makassar \\ Email :seprianp14@gmail.com
}

CC 10 (1) 2020 - UEJ Program Studi Pendidikan Kependudukan dan Lingkungan Hidup
Universitas Negeri Makassar. Ini adalah artikel dengan akses terbuka
dibawah Licensi CC BY-NC-4.0(http:/creativecommons.org/licenses/by-nc/4.0)

\begin{abstract}
Abstrak.
Penelitian ini adalah penelitian kuantitatif dengan pendekatan Survay dengan analisis deskriptif. Penelitian ini bertujuan untuk mengambarkan mengenai bagaimana Pelaksanaan program adiwiyata dimulai dari perencanaan, pelaksanaan, monitoring. Populasi dalam penelitian ini adalah seluruh warga sekolah yang ada di SMP Negeri 17 Makassar dengan jumlah sampel 130 orang peserta didik dan 3 guru. Teknik pengumpulan data dalam penelitian ini adalah mengunakan angket dan diperdalam melalui wawancara. Hasil uji statistik deskriptif menunjukkan bahwa pengetahuan lingkungan peserta didik SMP Negeri 17 Makassar termasuk kategori tinggi, sikap lingkungan peserta didik SMP Negeri 17 Makassar termasuk kategori tinggi, partisipasi lingkungan peserta didik SMP Negeri 17 Makassar termasuk kategori sedang. sementara pencanaan, pelaksanaan, dan monitoring sudah berjalan dengan baik. Dengan demikian dapat disimpulkan bahwa program adiwiyata sudah memberikan pengaruh positif pada pengetahuan lingkungan peserta didik dan sikap peserta didik dalam memelihara lingkungan sedangkan partisipasi peserta didik dalam memelihara lingkungan belum memberikan dampak positif. Sementara pada perencanaan, pelaksanaan, dan monitoring sudah terlaksana dengan baik.
\end{abstract}

Kata Kunci : Perencanaan, Pelaksanaan, Monitoring, Pendidikan, Lingkungan Hidup.

\section{PENDAHULUAN}

Kerusakan lingkungan mulai mendapatkan perhatian pada tahun 1960-an dimana berkurangnya sumber daya alam, pengotoran udara, menurunnya kualitas air, pemanasan global, pelobangan lapisan ozon, berkurangnya keragaman hayati yang mengharuskan manusia untuk menemukan suatu relasi yang benar dalam perspektif hubungan yang tidak saling mematikan antara kegitan manusia dengan lingkungan. Masalah lingkungan hidup pada dasarnya timbul karena adanya perubahan yang menyebabkan lingkungan tidak mampu mendukung kehidupan manusia (Rusdiana, 2012). 
Kondisi lingkungan hidup pada saat ini semakin memprihatinkan karena dipicu oleh aktivitas manusia yang mengekploitasi sumberdaya alam dan lingkungan tanpa batas. Perilaku manusia terhadap kondisi sumberdaya alam dan lingkungan cenderung tidak peduli terhadap kerusakan yang terjadi, maka dari itu mengubah perilaku menjadi prioritas utama untuk mengatasi krisis lingkungan. krisis lingkungan yang terjadi bisa diatasi dengan melakukan perubahan cara pandang dan perilaku manusia terhadap alam yang fundamental. Untuk itu jalur pendidikan merupakan salah satu cara dalam upaya mengubah perilaku (Mulyana, 2009).

Pendidikan merupakan salah satu prioritas utama yang dilakukan oleh pemerintah. Hal tersebut telah dijelaskan dalam Pembukaan Undang-Undang Dasar 1945 dimana pendidikan merupakan salah satu sarana untuk meningkatkan kecerdasan dan keterampilan manusia sehingga kualitas sumber daya manusia sangat tergantung dari kualitas pendidikan. Melalui pendidikan seseorang dapat mengembangkan kemampuan pribadi, daya pikir dan tingkah laku yang lebih baik. Perkembangan ilmu pengetahuan dan teknologi menuntut peningkatan mutu pendidikan. Pengaruh berkembangnya ilmu pengetahuan dan teknologi pada sektor pembangunan sangat luas. Pendidikan sangat berperan untuk menyiapkan sumber daya manusia yang mampu berpikir secara mandiri dan kritis, karena pendidikan merupakan modal dasar bagi perkembangan pembangunan manusia yang berkualitas.

Berdasarkan Undang-Undang Nomor 20 Tahun 2003 Tentang Pendidikan Nasional dimana pendidikan merupakan usaha sadar dan terencana untuk mewujudkan suasana belajar dan proses pembelajaran agar peserta didik secara aktif mengembangkan potensi dirinya untuk memiliki kekuatan spiritual keagamaan, pengendalian diri, kepribadian, kecerdasan, akhlak mulia, serta keterampilan yang diperlukan dirinya, masyarakat, bangsa dan Negara. Pemerintah Indonesia membuat suatu kebijakan yang diterapkan dalam dunia pendidikan yang tertera dalam pasal 65 poin keempat Undang-Undang Nomor 32 Tahun 2009 Di mana dalam pasal tersebut menjelaskan bahwa "setiap orang berhak dan berperan dalam pengelolaan lingkungan hidup". Dari pernyataan tersebut pemerintah dalam hal ini adalah institusi pendidikan dimaksudkan ikut serta dalam melaksanakan pengelolaan lingkungan melalui pencanangan program sekolah Adiwiyata. 
Seprian Patandianan, Analisis Pelaksanaan Program Adiwiyata

Kementerian Lingkungan Hidup pada tahun 2006 mencanangkan Program Adiwiyata sebagai tindak lanjut dari MoU Nomor : Kep.07/MENLH/06/2005 dan Nomor : 05/VI/KB/2005 Tentang pembinaan dan pengembangan lingkungan hidup pada tanggal 3 Juni 2005 antara Menteri Lingkungan Hidup dan Menteri Pendidikan Nasional. Program Adiwiyata sendiri baru mulai tahun 2006 ini dilaksanakan dan dikhususkan untuk Pulau Jawa, karena Kementerian Lingkungan Hidup masih mencari model untuk kriterianya. Tetapi sejak tahun 2007 program ini kemudian dilaksanakan menyeluruh ke tiap provinsi yang ada di Indonesia. Program Adiwiyata diharapkan dapat menciptakan kondisi yang nyaman dalam pembelajaran serta timbulnya tanggung jawab lingkungan dalam rangka pembangunan berkelanjutan. Lingkungan yang bersih dan nyaman diyakini akan menambah semangat belajar serta menciptakan kondisi yang tidak membosankan (Windrianingsih, 2014).

Di kota Makassar upaya pelestarian lingkungan, pengendalian kerusakan lingkungan dan pengendalian pencemaran lingkungan dilakukan melalui program adiwiyata, program ini sudah diterapkan dibeberapa sekolah dikota Makassar salah satunya di SMP Negeri 17 Makassar yang telah menerapkan program adiwiyata sejak tahun 2009, dimana sekolah ini berhasil menyandang status sekolah adiwiyata tingkat kabupaten/kota, tingkat provensi, tingkat nasional dan pada tahun 2013 SMP Negeri 17 Makassar berhasil meraih penghargaan adiwiyata Mandiri. Didalam proses menuju sekolah adiwiyata membutuhkan waktu relatif panjang, sehingga butuh perencanaan matang serta kesinambungan upaya kerja keras segenap warga sekolah.

Berdasarkan penaparan diatas, peneliti akan mengkaji kondisi secara nyata gambaran pengetahuan, sikap, dan partisipasi serta bagaimana gambaran program adiwiyata ini apakah sudah berjalan sebagai mestinya, sehingga peneliti tertarik mengangkatan topik penelitian yang berjudul "Analisis Pelaksanaan Program Adiwiyata Di Kota Makassar". Sekolah yang menjadi fokus penelitian ini adalah SMP Negeri17 Makassar.

Adapun tujuan penelitian sebagai berikut : (1). Untuk mengetahui perencanaan program adiwiyata pada SMP Negeri 17 Makassar (2). Untuk mengetahui pelaksanaan program adiwiyata pada SMP Negeri 17 Makassar (3). Untuk mengetahui monitoring program adiwiyata pada SMP Negeri 17 Makassar.

\section{METODE}


Penelitian ini adalah penelitian kuantitatif dengan pendekatan Survay. Dimana penelitian ini merupakan penelitian yang bertujuan menjelaskan fenomena yang ada dengan menggunakan angka-angka untuk mencandarkan karakteristik individu atau kelompok (Syamsudin \& Damiyanti, 2011). Metode penelitian kuantitatif dapat diartikan sebagai metode penelitian yang berlandaskan pada filsafat positivisme, digunakan untuk meneliti pada populasi atau sampel tertentu, teknik pengambilan sampel pada umumnya dilakukan secara random, penggumpulan data menggunakan instrument penelitian, analisis data bersifat kuantitatif/statistik (Sugiyono, 2013). Penelitian ini dimaksudkan untuk mendapatkan gambaran dan keterangan-keteranggan dari responden mengenai Pengetahuan, Sikap, Partisipasi pada sekolah adiwiyata dan bagaimana keterlaksaan program adiwiyata yang dimulai perencanaan, pelaksanaan, monitoring di SMP Negeri 17 Makassar. Teknik Pengambilan sampel dalam penelitian secara Purposive Sampling. Purposive Sampling merupakan teknik penentuan sampel dengan pertimbangan tertentu (Sugiyono, 2012). Adapun jumlah sampel 130 Orang peserta didik dan 3 orang guru. Teknik Analisis Datadengan teknik analisis data statistik deskriptif. Analisis statistik deskriptif dilakukan untuk dengan mendeskripsikan data yang diperoleh dalam bentuk disribusi frekuesi, histogram, mudus, median, rata-rata, simpangan baku (standar deviasi) digunakan untuk mengkategorikan capaian rata yang diperoleh dari kuesioner/angket Pengetahuan sikap dan partisipasi serta perencanaan, pelaksanaan dan monitoring kuesioner/angket.

\section{HASIL PEMBAHASAN}

\section{Perencanaan Program}

Perencanaan program adiwiyata di SMP Negeri 17 Makassar dari hasil penelitian menujukan bahwa berdasarkan hasil analisis data kuantitatif menujukan bahwa $100 \%$ responden menujukan bahwa perencanaan dilakukan dengan kerjasama tim program adiwiyata yang kuat dengan melibatkan seluruh warga sekolah, dinas lingkungan, dinas pendidikan dan kebudayaan. Perencanaan ini dilakukan dengan memperhatikan karakteristik, situasi dan kondisi yang terdapat di sekolah. Demikian pula pada tim sudah melakukan kajian-kajian terkait sampah dan air, hasil kajian tersebuat dituangkan dalam rencangan aksi peduli dan berbudayaan lingkungan. Dari sisi yang lain penelitian ini menujukan bahwa program adiwiyata memberikan dampak yang baik bagi tim program adiwiyata dan wargasekolah terutama di tenangan pendidik 
disekolah karena seiring berjalan program ini meraka mulai memahani program ini. Dalam proses perencanaan ini pula dituangkan sebuah kegiatan pelatihan ataupun seminar terkait pembuatan RPP yang terintengrasi dengan mata pelajaran. Sementara untuk perencanaan anggaran perlindungan dan pengelolaan lingkungan hidup sudah sudah direncanakan pada saat perencanaan manum secara jelasnya anggaran tersebut akan dituangkan pada pelaksanaan kebijakan sekolah, namun disisi lain ditemukan bahwa belum adanya sarjana teknik lingkungan dan pendidikan lingkungan sekolah, selama ini sekolah hanya menggunakan tim ahli dari dinas lingkungan hidup hal ini menujukkan bahwa masih kurang pengawasan terhadap program ini akan tetapi dampak yang berbeda di tujukkan apabila sekolah memiliki sarjana ahli dibidang lingkungan karena pengawasan langsung dilapangan serta pembinaan langsung program ini.

\section{Pelaksanaan Program}

\section{a. Kebijakan Berwawasan Lingkungan}

Kebijakan Berwawasan Lingkungan, dimana Pengelolaanan lingkungan hidup merupakan salah satu upaya yang dilakukan untuk mengatasi kerusakan lingkungan dan kelangkaan sumber daya alam yang saat ini sedang terjadi. Menurut Arifin (2001) pengelolaan lingkungan hidup dan sumber daya alam merupakan upaya serius dan berkesinambungan mengenai harmonisme sains, etika dan praktis kebijakan.Pelaksanaan kebijakan berwawasan lingkungan program adiwiyata di SMP Negeri 17 Makassar dari hasil penelitian menujukan bahwa berdasarkan hasil analisis data kuantitatif dapat dilihat pada Tabel 1 dibawah ini :

Tabel 1. Persentase Pelaksanaan Kebijakan Berwawasan Lingkungan

\begin{tabular}{|c|c|c|c|}
\hline \multirow[b]{2}{*}{ No. } & \multirow[b]{2}{*}{ Standar } & \multicolumn{2}{|c|}{ Persentase $(\%)$} \\
\hline & & Terlaksana & $\begin{array}{c}\text { Tidak } \\
\text { Terlaksana }\end{array}$ \\
\hline A & $\begin{array}{l}\text { Kurikulum Tingkat } \\
\text { Pendidikan (KTSP) memuat kebijakan } \\
\text { upaya perlindungan dan pengelolaan } \\
\text { lingkungan hidup }\end{array}$ & $62.5 \%$ & $37.5 \%$ \\
\hline B & $\begin{array}{l}\text { Rencana Kegiatan dan Anggaran Sekolah } \\
\text { (RKAS) memuat program dalam upaya } \\
\text { perlindungan dan pengelolaan lingkungan } \\
\text { hidup }\end{array}$ & $90 \%$ & $10 \%$ \\
\hline
\end{tabular}

Pada tabel di atas menujukkan bahwa standar pertama mengenai kurikulum tingkat satuan pendidikan (KTSP) memuat kebijakan upaya perlindungan dan 
pengelolaan lingkungan hidup telah terlaksana 62,5\% dan yang belum terlaksana 37,5 \%. Keterlaksana pada program meliputi Visi Misi dan Tujuan sekolah tertuang kebijakan perlindungan dan pengeloloaan lingkungan hidup, kebijakan pencegah pencemaran dan kerusakan lingkungan hidup, serta pada Kriteria Ketuntasan Minimal pada indikator pembelajaran lingkungan Hidup secara terintegrasi dimana responden berpandapat berbeda mengenai hal ini. Sementara yang belum terlaksana pembelajaran khusus lingkungan hidup melalui kelas peminatan. Seharunnya kebijakan ini pembelajaran khusus lingkungan hidup melalui kelas peminatan harus dilaksanakan dan dibuat sekolah yang akan sangat membantu dalam menambah wawasasa lingkungan hidup peserta didik.

Pada standar kedua yaitu rencana kegiatan dan anggaran sekolah (RKAS) memuat program dalam upaya perlindungan dan pengelolaan lingkungan hidup sudah terlaksana $90 \%$ dan belum terlaksana $10 \%$. Program adiwiyata yang sudah dilaksanakan berkaitan rencana kegitan dan anggaran sekolah (RKAS) seperti kegitan kesiswaan dalam melaksanakan ekstrakurukuler dalam bidang lingkungan, Pengembangan kurikulum dan kegitan lingkungan hidup, kapasitas pengembangan mutu tenaga pendidik, sarana dan prasarana yang berkaitan dengan program adiwiyata. Pada Peran serta masyarakat dan kemitraan juga responden berpandapat berbeda mengenai hal ini.

\section{b. Pelaksanaan Kurikulum Berwawasan Lingkungan}

Kurikulum berbasis lingkungan merupakan salah indikator keberhasil program adiwiyata dimana kurikulum yang memuat tentang upaya perlindungan dan pengelolaan lingkungan hidup yang disampaikan dengan menggunakan strategi, metode, maupun sumber belajar oleh guru di sekolah. Menurut Fajarisma (2014) mengatakan bahwa kurikulum berbasis lingkungan secara sederhana dapat diimplementasikan dengan cara penyampaian materi lingkungan hidup melalui kurikulum yang beragam untuk memberikan pemahaman tentang lingkungan hidup yang dikaitkan dengan kehidupan sehari-hari. Pada pelaksanaan kurikulum berwawasan lingkungan program adiwiyata di 
SMP Negeri 17 Makassar dari hasil penelitian menujukan bahwa berdasarkan hasil analisis data kuantitatif dapat dilihat pada Tabel 2 dibawah ini :

Tabel 2. Persentase Pelaksanaan Kurikulum Berbasis Lingkungan

\begin{tabular}{|c|c|c|c|c|}
\hline \multirow[b]{2}{*}{ No. } & \multirow[b]{2}{*}{ Standar } & \multicolumn{3}{|c|}{ Persentase (\%) } \\
\hline & & Terlaksanan & $\begin{array}{l}\text { Kadang- } \\
\text { kadang }\end{array}$ & $\begin{array}{c}\text { Tidak } \\
\text { Terlaksanan }\end{array}$ \\
\hline A & $\begin{array}{lr}\text { Tenaga pendidik } & \text { memiliki } \\
\text { kompetensi } & \text { dalam } \\
\text { mengembangkan } & \text { kegiatan } \\
\text { pembelajaran } & \text { lingkungan } \\
\text { hidup } & \\
\end{array}$ & $94.44 \%$ & $0 \%$ & $5.56 \%$ \\
\hline B & 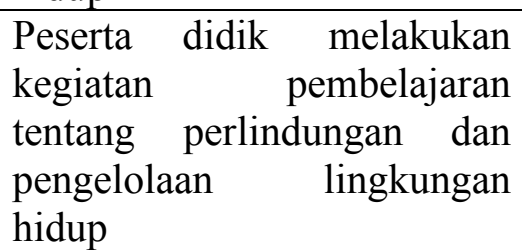 & $75 \%$ & $25 \%$ & $0 \%$ \\
\hline
\end{tabular}

Pada tabel di atas menujukkan bahwa pada standar pertama Tenaga pendidik memiliki kompetensi dalam mengembangkan kegiatan pembelajaran lingkungan hidup yang terlaksana yaitu $94.44 \%$ dan belum terlaksana $5.56 \%$ sementara untuk standar kedua tentang Peserta didik melakukan kegiatan pembelajaran tentang perlindungan dan pengelolaan lingkungan hidup sudah terlaksana $75 \%$ dan $25 \%$ masih kadangkadang dilakukan.

Dalam Pelaksanaan kurikulum berbasis lingkungan dilakukan standar tenaga pendidik memiliki kompetensi dalam mengembangkan kegiatan pembelajaran lingkungan dan peserta didik melakukan kegiatan pembelajaran tentang perlindungan dan pengelolaan lingkungan hidup. Berdasarkan hasil penelitian di SMP Negeri 17 Makassar dengan 2 orang responden telah memenuhi komponen pendidik memiliki kompetensi dalam mengembangkan kegiatan pembelajaran lingkungan. Dalam kegiatan pembelajaran guru menerapkan strategi, metode, dan teknik pembelajaran partisipatif. misalya menggunakan menggunakan metode pembelajaran ceramah, diskusi, pembelajaran di luar kelas (pengalaman lapangan), praktik di laboratorium, dan penugasan yang berkaitan dengan lingkungan. Kemudian guru telah mengembangkan isu lokal dan global sebagai materi pembelajaran lingkungan hidup melalui kegiatan berceramah. Guru juga mengembangkan indikator dan instrumen penilaian pembelajaran lingkungan hidup pada mata pelajaran yang terintegrasi dengan PLH. 
Guru menyusun rancangan pembelajaran lengkap yang terdapat dalam RPP. Selain itu guru juga telah menghasilkan inovasi pembelajaran dan karya-karya kemudian mempublikasikannya.

Pada komponen peserta didik melakukan kegiatan pembelajaran tentang perlindungan dan pengelolaan lingkungan hidup, peserta didik SMP Negeri 17 Makassar telah melaksanakannya dengan peserta didik menghasilkan karya nyata yang berkaitan dengan pelestarian fungsi lingkungan, adapun karya yang dihasilkan antara lain karya kerajinann dari plastik, botol-botol dibuat hiasan. Selain itu peserta didik mengomunikasikan hasil pembelajaran lingkungan hidup dengan berbagai cara salah satunya yaitu melalui mading sekolah.

\section{c. Kegiatan Lingkungan Berbasis Partisipatif}

Menurut Dwiningrum (2015) partisipasi merupakan keterlibatan mental dan emosional dari seseorang didalam situasi kelompok yang mendorong mereka untuk menyokong kepada pencapaian tujuan pada kelompok tersebut dan ikut bertanggungjawab pada kelompoknya. Pada pelaksanaan kegiatan lingkungan berbasis partisipasif program adiwiyata di SMP Negeri 17 Makassar dari hasil penelitian menujukan bahwa berdasarkan hasil analisis data kuantitatif dapat dilihat pada Tabel 3 dibawah ini :

Tabel 3. Persentase Pelaksanaan Kegiatan Lingkungan Berbasis Partisipasif

\begin{tabular}{|c|c|c|c|c|}
\hline \multirow[b]{2}{*}{ No. } & \multirow[b]{2}{*}{ Standar } & \multicolumn{3}{|c|}{ Persentase (\%) } \\
\hline & & Terlaksana & $\begin{array}{l}\text { Kadang- } \\
\text { kadang }\end{array}$ & $\begin{array}{c}\text { Tidak } \\
\text { Terlaksanan }\end{array}$ \\
\hline A & $\begin{array}{lr}\text { Melaksanakan } & \text { kegiatan } \\
\text { perlindungan } & \text { dan } \\
\text { pengelolaan } & \text { lingkungan } \\
\text { hidup yang terencana bagi } \\
\text { warga sekolah }\end{array}$ & $84.21 \%$ & $10.53 \%$ & $5.26 \%$ \\
\hline B & $\begin{array}{l}\text { Menjalin kemitraan dalam } \\
\text { rangka perlindungan dan } \\
\text { pengelolaan lingkungan } \\
\text { hidup dengan berbagai pihak } \\
\text { (masyarakat, pemerintah, } \\
\text { swasta, media, sekolah lain) }\end{array}$ & $73.33 \%$ & $6.67 \%$ & $20.00 \%$ \\
\hline
\end{tabular}


Pada tabel di atas menujukkan bahwa pada standar pertama melaksanakan kegiatan perlindungan dan pengelolaan lingkungan hidup yang terencana bagi warga sekolah sudah terlaksana $84.21 \%$, kadang-kadang dilaksanakan $10.53 \%$ dan belum terlaksana $5.26 \%$ sementara pada standar kedua yaitu menjalin kemitraan dalam rangka perlindungan dan pengelolaan lingkungan hidup dengan berbagai pihak (masyarakat, pemerintah, swasta, media, sekolah lain) sudah terlaksana $73.33 \%$ dan $20.00 \%$ belum terlaksaan sementara $6.67 \%$ masih kadang-kadang.

Dalam pelaksanaannya di sekolah kegiatan lingkungan yang terencana bagi warga sekolah dimana sekolah telah melaksanakan beberapa kegiatan, yaitu kegiatan pemeliharaan dan perawatan gedung dan lingkungan sekolah yang dilakukan dengan membuat piket kelas, piket kolam ikan, piket menyiram tanaman, piket kamar mandi. Kemudian memanfaatkan lahan dan fasilitas sekolah sesuai kaidah perlindungan dan pengelolaan lingkugan hidup, dilakukan oleh sekolah dengan membangun ruang hijau terbuka, kolam ikan, penanaman pohon perindang, tempat penglolaan sampah. Mengembangkan kegiatan ekstrakurikuler yang sesuai dengan upaya perlindungan dan pengelolaan lingkungan hidup, yaitu pengintegrasian PLH pada seluruh ekstarkurikuler yang diselenggarakan oleh sekolah. Standar yang kedua yaitu sekolah menjalin kemitraan dalam rangka perlindungan dan pengelolaan lingkungan hidup. Sekolah telah menjalin kerjasama dengan BLH, puskesmas tamangapa Dinas Lingkungan Hidup Kota Makassar, dan Dinas Pendidikan Kota Makassar dan kemitraan dengan beberapa sekolah.

\section{d. Pengelolaan Sarana Pendukung Ramah Lingkungan}

Sarana dan prasarana adalah semua fasilitas yang diperlukan dalam proses belajar mengajar baik yang bergerak maupun tidak bergerak, yang secara langsung maupun tidak langsung dapat berpengaruh terhadap tujuan pendidikan (Amirin, 2013) Pada pelaksanaan Pengelolaan Sarana Pendukung Ramah Lingkungan program adiwiyata di SMP Negeri 17 Makassar dari hasil penelitian menujukan bahwa berdasarkan hasil analisis data kuantitatif dapat dilihat pada Tabel 4 dibawah ini :

Tabel 4.5. Presentase Pelaksanaan Pengelolaan Sarana Pedukung Ramah Lingkungan

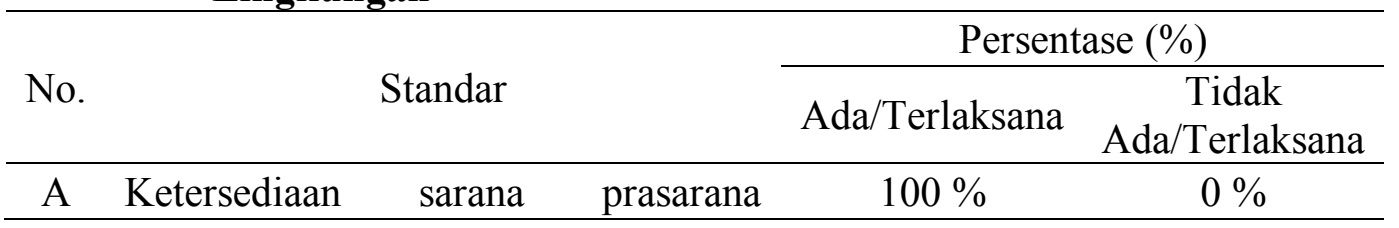




\begin{tabular}{lll}
\hline pendukung yang ramah lingkungan & & \\
\hline B & $\begin{array}{l}\text { Peningkatan kualitas pengelolaan dan } \\
\text { pemanfaatan sarana dan prasarana } \\
\text { yang ramah lingkungan }\end{array}$ & $100 \%$ \\
\hline
\end{tabular}

Pada tabel di atas menujukkan bahwa pada standar pertama ketersediaan sarana prasarana pendukung yang ramah lingkungan sudah terlaksana $100 \%$ demikian pula pada standar kedua tentang Peningkatan kualitas pengelolaan dan pemanfaatan sarana dan prasarana yang ramah lingkungan. Dalam melaksanakan beberapa kegiatan yang berkaitan dengan pengelolaan sarana dalam rangka mendukung program Adiwiyata dimana sekolah menyediakan sarana dan prasarana yang sesuai dengan standar sarana dan prasarana pendidikan serta ramah lingkungan.

Sarana dan prasarana di SMP Negeri 17 Makassar telah terlaksana seperti sarana air bersih, tempat sampah yang terpisah sesuai jenis sampah, ruang terbuka hijau, biopori, sumur resapan, komposter, serta kantin bersih dan sehat. Kondisi lahan sekolah sudah mendukung untuk pelaksanaan kegiatan belajar mengajar dan pelaksanaan kegiatan yang mendukung program Adiwiyata. Kondisi bangunan sekolah juga sangat mendukung proses pembelajaran, penerangan dan ventilasi udara sudah optimal. Peningkatan kualitas pengelolaan dan pemanfaatan sarana dan prasarana yang ramah lingkungan yang dilakukan dengan optimalisasi piket, yang terdiri atas piket ruang kelas, piket kamar mandi, piket menyiram tanaman, dan piket kolam. Untuk peningkatan kualitas kantin sehat dan ramah lingkungan. Dalam buku Panduan Adiwiyata (2016: 16) disebutkan bahwa upaya dalam peningkatan kualitas kantin dapat dilakukan dengan meningkatkan kualitas pelayanan kantin sehat dan ramah lingkungan, yang meliputi kantin tidak menjual makanan/minuman yang mengandung bahan pengawet/ pengenyal, pewarna, perasa yang tidak sesuai dengan standar kesehatan; kantin tidak menjal makanan tercemar/terkontaminasi, dan kadaluarsa; kantin tidak menjual makanan dikemas tidak ramah lingkungan seperti plastik, styrofoam, dan aluminium foil. SMP Negeri 17 Makassar telah meningkatkan kualitas pelayanan kantin yang sehat dan ramah lingkungan dengan melakukan kerja sama dengan puskesmas. akan tetapi Kantin masih menjual menjual makanan plastic/ Styrofoam.

\section{Monitoring Program}


Dalam proses monitoring atau pegawasan dilakukan pihak pada tahap perencanaan dan pelaksanaan program sudah sesuai dengan prosedur dan dari wawacara pada responden dan di dominasi pada jawaban terlaksana. Dalam penelitian ini monitoring/pegawasan kesesuaian pelaksanaan kurikulum dengan kebijakan yang telat dibuat telah terlaksaan dan pengawasan terhadap tenaga pendidik dalam pelaksanaan kurikulum berbasis lingkungan hidup (Terintegrasi) diawasi langsung oleh bagian kurikulum dan dievaluasi setiap semester. Sementara itu pengawasan terhadap rencana kegiatan dan anggaran sekolah (RKAS) yang berkaitan langsung dengan program adiwiyata diawasi langsung oleh kepala sekolah dan bendahara sekolah dan dilakukan secara transparasi. Dalam proses monitoring atau pegawasan dilakukan pihak pada tahap perencanaan dan pelaksanaan program sudah sesuai dengan prosedur dan dari wawacara pada responden dan di dominasi pada jawaban terlaksana. Dalam penelitian ini monitoring/pegawasan kesesuaian pelaksanaan kurikulum dengan kebijakan yang telat dibuat telah terlaksaan dan pengawasan terhadap tenaga pendidik dalam pelaksanaan kurikulum berbasis lingkungan hidup (Terintegrasi) diawasi langsung oleh bagian kurikulum dan dievaluasi setiap semester. Sementara itu pengawasan terhadap rencana kegiatan dan anggaran sekolah (RKAS) yang berkaitan langsung dengan program adiwiyata diawasi langsung oleh kepala sekolah dan bendahara sekolah dan dilakukan secara transparasi. Kemudian Pegawasan terhadap pelaksanakan kegiatan perlindungan dan pengelolaan lingkungan hidup yang sudah di rencanakan bagi warga sekolah diawasi semua guru yang ada sekolah. Pegawasan terhadap kondisi sarana prasarana pendukung yang ramah lingkungan dilakukan langsung oleh bagian sarana dan prasana dalam bila terdapat kerusakan yang dilihat oleh warga sekolah dilaporkan langsung pada bagi terkait. Pengawasan terkait makanan kantin melibatkan petugas puskesmas tamanggapa yang dilakukan pertiga bulan sekali yang didasarkan pada hasil wawancara hal ini seharusnya pihak sekolah harus terlibat aktif dalam pengawasan kantin sekolah untuk mengawasi kemasan penjualan yang ada disekolah termasuk penggunaan plastik dan dan kemasan makanan yang dari styrofom. Pengawasan terhadap penggunaan listrik dan penggunaan air dilakukan setiap bulannya oleh petugas sekolah yang sudah diamanahkan. Dari penjelasan di atas penulis menyimpulkan bahwa monitoring program adiwiyata di SMP Negeri 17 Makassar sudah berjalan dengan baik. 


\section{REFERENSI}

Depdiknas .2003. Undang-undang RI No.20 tahun 2003.tentang sistem pendidikan nasional.

Kementrian Lingkungan Hidup Republik Indonesia. 2010. Pendidikan Lingkungan Hidup.http://www.menlh.go.id/pendidikan lingkungan hidup/ .Diakses 10 april 2018.

Kementrian Lingkungan Hidup. 2010. Panduan Adiwiyata 2012. Jakarta: KLH.

Rusdiana. A. 2012. Ilmu Sosial dan Budaya Dasar. Bandung: Pustaka Tresna Bhakti

Sugiyono. 2012. Metode Penelitian Bisnis. Bandung : CV. Alfabet

Sugiyono. 2013. Memahami Penelitian Kualitatif. Bandung : CV. Alfabet

Windrianingsih, Sinta Selvi. 2014. Kebijakan Sekolah Dan Partisipasi Siswa Dalam Pelaksanaan Program Sekolah Adiwiyata Di Smp Negeri 1 Jakenan Kabupaten Pati 11(2): 11. 